\title{
Physicochemical Analysis of Groundwater Samples of Bichi Local Government Area of Kano State of Nigeria
}

\author{
Emmanuel Bernard ${ }^{1, *}$, Nurudeen Ayeni \\ ${ }^{1}$ Department of Chemistry, Federal College of Education (Technical) Bichi, P.M.B 3473 Kano, Nigeria \\ ${ }^{2}$ Department of Chemistry, Federal College of Education, P.M.B 3045, Kano, Nigeria
}

\begin{abstract}
The physicochemical properties of groundwater from various locations in Bichi Local Government Area of Kano State were analysed using standard methods. The samples taken from twenty different locations revealed that the study area has a mean of Turbidity $2.0 \mathrm{NTU}$, Colour $2.5 \mathrm{TCU}$, Temp. $25^{\circ} \mathrm{C}, \mathrm{P}^{\mathrm{H}} 6.8$, Total A lkalinity $85.0 \mathrm{mg} / 1$, Total Hardness $71.83 \mathrm{mg} / 1$, and others are: Calcium $25.24 \mathrm{mg} / 1$, Magnesium $2.19 \mathrm{mg} / 1$, Iron 0.05 , Chloride $7.89 \mathrm{mg} / 1$, Nitrate $0.79 \mathrm{mg} / 1$, Total dissolved solid 81.0 $\mathrm{mg} / \mathrm{l}$, and Conductivity $135 \mu \mathrm{S} / \mathrm{cm}$. The study was geared towards ascertaining the quality of ground water in the area and, it was observed that the water samp les were within World Health Organization (W HO) and Standard Organization of Nigeria (SON) permissible limit for ground water which satisfy the safety limit for its use for various purposes like domestic, agricultural, and industrial. It was suggested that there should be regular monitoring and control of human activities to protect the ground water from contaminations.
\end{abstract}

Keywords Physicochemical, Properties, Groundwater, Bichi, Drinking, Water

\section{Introduction}

Water as a universal solvent has the ability to dissolve many substances be it organic or inorganic compound. With this outstanding property, nevertheless it is almost impossible to have water in its pure form since it cannot be held up in a vacuum. Water which occurs below the water table is referred to as groundwater, it supports; drinking water supply, livestock needs, irrigation, industrial and many other commercial activities. The quality of ground water depends on various chemical constituents and their concentration, which are mostly derived from the geological data of the particular region. Groundwater is generally less susceptible to contamination and pollution when compared to surface water bodies.[1, 3]

In Bichi, groundwater is one of the main sources of water used intensively for domestic and agricultural purposes, Uncensored human activities in developing countries including Nigeria contribute immensely to the poor quality of groundwater. The problems of water quality are much more acute in areas which are densely populated, with localization of industries. Importantly, groundwater can also be contaminated by naturally occurring sources. A number of chemical contaminants have been shown to cause adverse health effects in humans as a consequence of prolonged exposure through drinking-water from various sources Much of ill health which

* Corresponding author:

royalhoodem@yahoo.com (Emmanuel Bernard)

Published online at http://journal.sapub.org/env

Copyright (C) 2012 Scientific \& Academic Publishing. All Rights Reserved affects humanity, especially in the developing countries can be traced to lack of safe and wholesome water supply.[4-7]

Water for human consumption must be free from living and non-living organis ms, to xic elements and chemical substances in concentration large enough to affect health.[1, 8, 9] .The addition of various kinds of pollutants through sewage, industrial effluents, agricultural run off etc, into the water main stream brings about series of changes in the physicochemical characteristics of the water, which have been the subject of several investigations.[10, 1, 12].

In Northwest Nigeria the pollution of groundwater was traced to shallow water table that intercepts pit latrines and soaks away pits.[13]. The water used for drinking purpose should be free from toxic elements, living and non-living organisms and excessive amount of minerals that may be harmful to health. Pollution caused by fertilizers and pesticides used in Agriculture, often dispersed over large areas, is a great threat to fresh groundwater ecosystems.

The probability that any particular chemical may occur in significant concentrations in any particular setting must be assessed on a case-by-case basis. The presence of certain chemicals may already be known within a particular country, but others may be more difficult to assess. The rate of human activities and the associated problems necessitate the need for regular ass essment of the water bodies. $[6,7,14]$

The water supply for human consumption in Bichi is often directly sourced from ground water without any chemical treatment and the fear of pollution has become a cause for major concern.

The objective of this study is to evaluate some of the parameters that can cause contamination and in what concen- 
tration if present, and comparing it with set standards of World Health Organization and Standard Organization of Nigeria.

\section{Materials and Methods}

\subsection{Description of Study Area}

Bichi Local Government Area is hosted by Kano state which is ranked second in population with about 9.0 million people and lies between latitude $11^{\circ} 30^{\prime}$ and $11.5^{\circ} \mathrm{N}$ and longitude $8^{\circ} 30^{\prime}$ and $8.5^{\circ} \mathrm{E}$. Nigeria is located approximately between latitude $4^{\circ}$ and $14^{\circ}$ North of the equator, and between longitude $2^{\circ} 2^{\prime}$ and $15^{\circ}$ east of the Greenwich meridian. ${ }^{[15]}$

\subsection{Collection/Treatment of Water Samples}

Samples were collected from twenty locations of drinking water in plastic containers previously washed with detergents and $\mathrm{HNO}_{3}$ acid and later rinsed with sampled water several times. $2 \mathrm{M} \mathrm{HNO}_{3}$ was added to samples for metallic ions determination, this is to maintain the stability of the oxidation state of the various elements in solution and prevent precipitation. ${ }^{[15][16][17]}$

\subsection{Physicochemical Analysis}

\section{Temperature}

The temperatures of the samples were measured at the point of collection using mercury in glass thermo meter.

Electrical conducti vity and $\mathrm{P}^{\mathrm{H}}$

The conductivity of the samples was determined using a Jenway model 4010 , and the $\mathrm{P}^{\mathrm{H}}$ Meter, model PBS - 51, EL Hama instrument was used to determine the $\mathrm{P}^{\mathrm{H}}$ value.

Tur bi dity

A turbidimeter model HACH $2100 \mathrm{Q}$ Colorado, was used to determine the turbidity of the samples.

\section{Total Alkalinity}

It was determined by titrimetric method using standard solution of $0.01 \mathrm{M} \mathrm{HCl}$ and methyl orange as indicator.

\section{Total Hardness}

It was measured using EDTA (Ethylene - Di amine Tetra Acetic Acid) as titrant with ammonium chloride and ammonium hydroxide buffer solution and Erichrome Black $\mathrm{T}$ as indicator.

\section{Chloride content}

It was determined by Mohr's method using silver nitrate as titrant and potassium chromate solution as indicator.

\section{Total Dissolve d Solid}

This was determined by evaporation method in an oven maintained at $200^{\circ} \mathrm{C}$ for $2 \mathrm{hrs}$.

\section{Calcium Har dness}

Calcium hardness was determined using EDTA method with mure xide (ammon ium purpate) as indicator.

The Cationics

$100 \mathrm{~cm}^{3}$ of the water sample was pre-concentration by heating in a vacuum until the sample was reduced to $25 \mathrm{~cm}^{3}$. Determination was done using the atomic absorption spectrophotometer, Model Alpha 4 for magnesium and iron and flame photometer, model PF7, Jen way for calcium

\section{Results and Discussion}

The result of physical and chemical parameters obtained fro $m$ the analysis of water samples are shown in Table 1.

The value of temperature in the study area ranged from 24.5 $-26.2^{\circ} \mathrm{C}$. It is noted that high water temperature enhances the growth of micro organis ms and may increase taste, odour, colour and corrosion problems.

The colour ranged from $1.8-3.0 \mathrm{TCU}$ which is within WHO and SON permissible limit. Colour in drinking-water is usually due to the presence of colour organic matter (primarily hu mic and fulvic acids) associated with the humus fraction of soil or the presence of iron and other metals, either as natural impurities or as corrosion products. ${ }^{[14]}$

The $\mathrm{P}^{\mathrm{H}}$ values of samp les range is $6.3-8.2$ wh ich conform to WHO and SON standard for drinking water. Although $\mathrm{pH}$ usually has no direct impact on consumers, it is one of the most important operational water quality para meters.

The conductivity concentrations range were $126-143 \mu$ $\mathrm{S} / \mathrm{cm}$ wh ich were below SON standard for drinking water.

The turbidity value of the study area ranged between $1.7-$ 2.4. Turbidity in drinking-water may be due to the presence of inorganic particulate matter in some groundwater or sloughing of biofilm within the distribution system. High turbid ity value can protect micro organisms from the effects of disinfection thereby can stimulate bacterial growth. The value is within WHO and SON standard for drinking water. ${ }^{[16][17]}$

The alkalinity of water may be caused by dissolved strong bases such as sodium or potassium hydroxide (and other hydroxide containing compounds), hydroxide ions are always present in water, even if the concentration is extremely small. The alkalinity value ranged between $74.3-88.2 \mathrm{mg} / \mathrm{l}$. When water has high alkalinity it is concluded that it is well buffered. It resists a decrease in $\mathrm{pH}$ when acidic ra in snowmelt, enters it. If water has an alka lin ity below about $100 \mathrm{mg} / \mathrm{L}$ as $\mathrm{CaCO}_{3}$, it is poorly buffered and $\mathrm{pH}$ sensitive. This could be harmful to the plants and animals that live there. ${ }^{[8][14][16]}$

The range of hardness analysed is $68.0-73.8 \mathrm{mg} / \mathrm{L}$ and fell below W.H.O and S.O.N standard of drinking water. Hardness caused by calcium and magnesium usually results in excessive soap consumption and subsequent "scum" formation. In so me instances, consumers tolerate water hardness in excess of 500 $\mathrm{mg} / \mathrm{l}$. Depending on the interaction of other factors, such as $\mathrm{pH}$ and alkalinity, water with hardness above approximately 200 $\mathrm{mg} / \mathrm{l}$ may cause scale deposition in the treatment works, distribution systemand pipe work and tanks within build ings. Soft water, with a hardness of less than $100 \mathrm{mg} / \mathrm{l}$, may, have a low buffering capacity and so be more corrosive for water pipes. ${ }^{[16][17][18]}$ 
Table 1. Physico-chemical Analysis of Ground Water in Bichi Local Govt. Area of Kano

\begin{tabular}{|c|c|c|c|c|}
\hline Parameters & Range & Mean & SON & WHO \\
\hline Temp. ${ }^{\circ} \mathrm{C}$ & $24.5-26.2$ & 25 & Ambient & \\
\hline Color TCU & $1.8-3.0$ & 2.5 & 15 & 15 \\
\hline $\mathrm{P}^{\mathrm{H}}$ & $6.3-8.2$ & 6.8 & $6.5-8.5$ & $6.5-9.5$ \\
\hline Conductivity. $\mu \mathrm{S} / \mathrm{cm}$, & $126-143$ & 135 & 1000 & \\
\hline Turbidity NTU & $1.7-2.4$ & 2.0 & 5 & 5 \\
\hline Alkalinity. (Methyl orange) mg/l & $74.3-88.2$ & 85.0 & & \\
\hline Harness.(as $\left.\mathrm{CaCO}_{3}\right) \mathrm{mg} / \mathrm{l}$ & $68.0-75.8$ & 71.83 & 150 & 500 \\
\hline Calcium. $\left(\mathrm{Ca}^{+2}\right) \mathrm{mg} / \mathrm{l}$ & $24.2-30.3$ & 25.24 & & $100-300$ \\
\hline Magnesium. $\left(\mathrm{Mg}^{+2}\right) \mathrm{mg} / 1$ & $2.00-4.67$ & 2.19 & & \\
\hline Chloride. $\mathrm{mg} / \mathrm{l}$ & $7.10-8.45$ & 7.89 & 250 & 250 \\
\hline $\operatorname{Iron}\left(\mathrm{Fe}^{+2}\right)$ & $0.00-0.05$ & 0.05 & 0.3 & 0.3 \\
\hline Nitrate. $m g / 1$ & $0.52-1.03$ & 0.79 & 50 & 50 \\
\hline TDS. mg/l & $79.0-86.7$ & 81.0 & 500 & $500-1000$ \\
\hline
\end{tabular}

SON (Standard Organization of Nigeria); WHO (World Health Organization)

The analysis of calcium revealed a range of between 24.2 30.3 and the W.H.O standard of drinking water indicates that the taste threshold for the calcium ion is in the range of $100-300 \mathrm{mg} / 1$, depending on the associated anion. Magnesium concentration in samples were in the range of $2.00-4.67$, both cations are the major cause of hardness in water $[4][17][18]$

Chloride in drin king-water originates from natural sources, sewage and industrial effluents, urban runoff containing de-icing salt and saline intrusion. No health-based guideline value is proposed for chloride in drinking-water by $\mathrm{WHO}$ and SON standard of drinking water. However, chloride concentrations in excess of about $250 \mathrm{mg} / \mathrm{l}$ can give rise to detectable taste in water and the observed range is 7.10 - 8.45 $\mathrm{mg} / \mathrm{l}^{[10][12][13]}$

Nitrate can reach both surface water and groundwater as a consequence of agricultural activity (including excess application of inorganic nitrogenous fertilizers and manures), but groundwater concentrations generally show relatively slow changes. Some ground waters may also have nitrate contamination as a consequence of leaching from natural vegetation The concentration range of $0.52-1.03 \mathrm{mg} / 1$ was observed which was below the WHO and SON standard of drinking water permissible limit. $\left[{ }^{10][11][13]}\right.$

Iron concentrations range was $0.00-0.05 \mathrm{mg} / \mathrm{l}$. It is noted that anaerobic groundwater may contain ferrous iron at concentrations of up to several $\mathrm{mg} / \mathrm{l}$ without discoloration or turbidity in the water when directly pumped from a well. On exposure to the atmosphere, however, the ferrous iron oxidizes to ferric iron, giving an objectionable reddish-brown color to the water. Iron also promotes the growth of "iron bacteria," which derive their energy from the oxidation of ferrous iron to ferric iron and in the process deposit a slimy coating on the piping. ${ }^{[10][13]}$

TDS values were in the range of $79.0-86.7 \mathrm{mg} / 1$, it comprises inorganic salts (principally calcium, magnesium, potassium, sodium, bicarbonates, chlorides and sulfates) and small amounts of organic matter that are dissolved in water. TDS in drinking-water originate from natural sources, sewage, urban runoff and industrial wastewater. Concentrations of TDS in water vary considerably in different geological reg ions owing to differences in the solubility of minerals. The palatability of water with a TDS level of less than $600 \mathrm{mg} / 1$ is generally considered to be good; drinking-water becomes significantly and increasingly unpalatable at TDS levels greater than about $1000 \mathrm{mg} / \mathrm{l}$. The presence of high levels of TDS may also be objectionable to consumers, owing to excessive scaling in water pipe, heaters, boilers and household appliances. No health-based guideline value for TDS has been proposed. Water with extremely low concentrations of TDS may also be unacceptable because of its flat, insipid taste. ${ }^{[8][14][17]}$

Bichi Local Government Area though not absolutely an urban and industrial area have a relatively high TDS concentration, which is an evidence that there are soluble mineral salts in the geographical region.

\section{Conclusions}

Informing the public of the state of their drinking water should be considered as an important aspect of social responsibility as well as scientific research. Consumers may be aware of a potential problem with the safety of drinking water because of media coverage or access to research work. Lack of confidence in the drinking-water or the authorities may drive consumers to alternative, potentially less safe sources.[3][10] Not only do consumers have a right to information on the safety of their d rin king-water, but they have an important role to play in assisting the authorities by their own actions and by carrying out the necessary measures at the individual level. Safe drinking water is vital to sustain life and a satisfactory (adequate, safe and accessible) supply must be available to all. Improving access to safe drinking-water can result in tangible benefits to health. Every effort should be made to achieve drinking-water quality as safe as practicable.[1][5]

The quality of ground water is the resultant of all the processes and reactions that act on the water from the mo ment it condensed in the atmosphere to the time it is discharged by a well or spring and varies from place to place and with the depth of the water table, in places where groundwater is majorly used, a variety of land and water based human activities are causing pollution of th is valuable resource. Pollution of groundwater due to industrial effluents and municipal waste in water bodies is a major concern in many cities and industrial clusters all over the world. There is thus the need for agencies responsible for environmental protection to 
constantly monitor and control the use of the area for agriculture and other human activities to keep the ground water safe from contamination[4][12][20]

The results obtained from the analysis of the samples revealed that the quality of ground water in Bichibeen assessed by comparing each concentration with the standard desirable limit for drinking water as prescribed by WHO and SON, are within permis sible limits.

\section{REFERENCES}

[1] Oteze G. E (1991). Potability of groundwater from the Rima Group aquifers in the Sokoto Basin. J. Min. Geol., 27(1): 17-24.

[2] Olobaniyi S. B, and Efe S. I (2007) Comparative assessment of rainwater and groundwater quality in an oil producing area of Nigeria: Environmental and health implications. J. Environ. Health Res., 6(2) 111-118.

[3] Jalali M (2005). Major ion chemistry of groundwater in the Bahar area, Hamadan, western Iran. Environ. Geol., 47: 763-772

[4] Kumar A, (2004) Water Pollution. Nisha Enterprises New Delhi.

[5] Mahananda, H. B, Mahananda, M.R. and Mohanty, B.P. (2005)"Studies on the Physco-chemical and Biological Parameters of a Fresh Water Pond Ecosystem as an Indicator of Water Pollution”. Ecol. Env \& Cons.11(3-4), 2005, pp 537-541.

[6] Standard Method for the Examination of Water and Wastewater, (1995). American Public Health Association (APHA), American Water Works Association (AWWA), Water Environment Federation, (WEF). $19^{\text {th }}$ Edition

[7] Bruvold WH, Ongerth HJ: (1969) “Taste Quality of Mineralized Water". Journal of The American Water works Association Vol. $61: 170$.
[8] Water System Council (2007) "Wellcare Publications" Retrieved from www.wellcarehotline.org.

[9] Brian O. (2007) Environmental Quality Centre Environmental Engineering and Earth Sciences Wilkes University. WilkesBarre, PA 1876. Webmaster.

[10] Ayodele, J. T and Abubakar, M. B, (1998). Trace Elements Contamination of Rainwater in the Semi arid Region of Kano. Nigeria. Journal of Environmental Management and Health, vol. 9 , No. 4

[11] WHO/UNEP, (1989), GEMS. Global Freshwater Quality. Oxford, Alden Press.

[12] Trivedy, R.K. (1990) "Phy sico-Chemical Characteristics and Phytoplankton of the River Panchganga ". River Pollution in India Ashish Publishing House, New Delhi, ,pp.159-178.

[13] Oteze, G. F (1993) Tropical soil in Nigeria in Engineering, Groundwater level and groundwater Management. Balkema Rotterdam, Netherland p. 172.

[14] World Health Organization,: (2011) Drinking Water Standards and Health Advisories Office of Water U.S. Environmental Protection Agency Washington, DC.

[15] Wikipedia (2012) Kano State of Nigeria, Wikimedia Foundation, Inc., Retrieved from http://en.wikipedia.org/w/ index.php?title=Kano_State\&oldid $=458252590$

[16] National Academy of Science. (1986) Eutrophication causes consequences and correctives. Nat. Acad. Sci. Washington, D.C.

[17] Standards Organization Of Nigeria (2007) Nigerian Standard for Drinking Water Quality Abuja, Nigeria.

[18] World Health Organization,: (2003) "Guidelines For Drinking Water Quality, Health Criteria and Other Supporting Information $2^{\text {nd }}$ Edition Vol. 2.

[19] World Health Organization,: (2008) Guidelines for Drinking-water Quality Incorporating the First and Second Addenda Volume 1 Recommendations, $3^{\text {rd }}$ Edition, Geneva. 